\author{
差異表現に基づくピクトグラムの主題提示と認識向上 \\ 藤森 誠*, 伊藤 一成**,****, Martin J. DÜRST ${ }^{* * *}$, 橋田 浩一**** \\ * 青山学院大学大学院 理工学研究科, ** 青山学院大学 社会情報学部, \\ *** 青山学院大学 理工学部, **** (独)産業技術総合研究所
}

\title{
TOPIC PRESENTATION AND RECOGNITION IMPROVEMENT USING DIFFERENTIAL PICTOGRAM EXPRESSIONS
}

\author{
Makoto FUJIMORI*, Kazunari ITO**,****, Martin J. DÜRST*** and Kōiti HASIDA**** \\ * Graduate School of Science and Engineering, Aoyama Gakuin University \\ ** School of Social Informatics, Aoyama Gakuin University \\ *** College of Science and Engineering, Aoyama Gakuin University, 5-10-1 Fuchinobe, Sagamihara-shi, Kanagawa 229-8558, Japan \\ **** National Institute of Advanced Industrial Science and Technology, 1-18-13 Sotokanda, Chiyoda, Tokyo 101-0021, Japan
}

\begin{abstract}
Pictograms are graphic symbols also called picture symbols. They are widely used, mainly in public accommodations. However, it is hard to say that meaning can be grasped quickly from a single pictogram. In most cases, pictograms are accompanied by some explanatory written text. In this paper, we propose a new method of displaying pictograms, displaying two slightly different pictograms successively, using the difference between the two frames to promote understanding. We limit ourselves to two frames because a higher number of pictograms makes it difficult to clearly express difference information and risks to confuse viewers more than help understanding. We experimentally evaluated the recognition properties of our new method. We showed one-frame and twoframe versions expressing the same content to 165 subjects and measured action time, percentage of correct answers, and semantic transparency. Using a Mann-Whitney U test, we found that in some problems, the semantic transparency was significantly $(p<0.05)$ higher for two-frame pictograms than for one-frame pictograms. Also, two-frame pictograms generally showed a better percentage of correct answers. We conclude that two-frame pictograms making use of difference information may contribute significantly to increasing pictogram recognition.
\end{abstract}

Keywords : Pictogram, Differential Expression, Topic Presentation

\section{1.はじめに}

ピクトグラムとは日本語で“絵文字”，“図記号”と呼ばれる グラフィックシンボルであり，意味するものの形状を使っ て，その意味概念を理解させる記号である [1]，その利用 用途は，交通標識やアイコン［2］などサインとしての役割 と, コミュニケーション実現や意思伝達の手段としての役割 [3-5］の 2 種類に大別できる. 近年, ユニバーサルデザイン の潮流もあり，世界中でピクトグラムへの注目とその利用が 広まりつつある。それに伴い, 国際的には ISO [6]や IEC [7] が, 日本ではJIS [8] を中心に, 様々な状況や用途を想定 したピクトグラムの規格が定められている。

特に, 空港, 駅, バス停, 市役所など公共施設を中心に多 数のピクトグラムがサイン用途で利用されている. 国内でい えば, 大衆に一番認知されているのは標準案内眓記号だろう [9]. さらに近年, より複雑な事象を表現した独自作成のピ クトグラムが世の中にあふれてきたのが特徴である。そのよ うな場合は, 極力既存のピクトグラム部品を複数組み合わせ て表現し，これにより再利用性や理解容易性を高めることが JIS などでも推奨されている. 我々はこの方針に基づいて,
これまでに組み合わせを考慮し部品化したピクトグラムを約 1000 個作成し Web 上で公開し普及に努めている ${ }^{1}$ 。また, 組合せピクトグラムの作成を支援するッールも同様に公開し ている

しかしながら標準案内図記号でさえ, おなじみの“非常口” や“トイレ”など場所を示す一部のピクトグラムを除けば, ピクトグラム単体で意味を瞬時に一般の人々が把握できてい るとは言い難いのが実情である。半は併記される単語や文 章によってはじめて表現内容が理解できる。 それ以外のピク トグラムは言うまでもない．併記した文章を精読しなければ ピクトグラムの学習, 言い換えれば情報伝達というピクトグ ラム表示の本来の目的が達成されない状況は望ましいとはい えない

我々はその一連の取り組みの中で, 関連性のある2 コマ のピクトグラムを連続的に提示することで, それらの差異部 分から文脈, 対比, 帰結関係などの意味をより正確に伝達で きるという仮説を立てるに至った，そこで，本論文では類似 ピクトグラムの連続提示と単体提示の認識特性を実験により 調査し, 反応時間や一致率, 意味明瞭度の結果に基ついてピ クトグラム単体での認識向上について考察する。

\footnotetext{
${ }^{1}$ http://sa.carc.jp/pict/
} 


\section{2. ピクトグラムの差異表現}

\section{1 概 要}

現在，コマ割り表現として動画が広く認知されている。動 画とは，動いている画像を指す。“多数の（時系列を細かく 分割した）画像を高速に切り替え続けると, 人間の視覚には それが連続的に見える”という特性を利用したものである。 動画形式のピクトグラムについては，わかりやすさ，視覚的 典型性, 意味明瞭度, 日常重要性などが北神らによって調査 されている [10].

しかし北神らの研究では, 動作（イディオグラム）を動画 形式のピクトグラムで表現することに主眼が置かれている. それに対し我々の研究は, 各コマの差異から得られる情報を 基に，ピクトグラムの意味理解を促進することを目的として いる点で異なる．本手法の目的はあくまで得られた差異情報 からピクトグラムの意味を特定することにある，そのため， コマ数をむやみに増やすと, 差異部分を特定し, 認識するこ とが困難となる．また，1コマ 1 コマが重要な意味を持つこ とになるので，コマ数が多すぎる場合情報過多となり，逆に 理解を妨げると考えられる。 そこで, 我々はコマ数を2 コ マに限定して, その 2 コマのピクトグラムを連続して提示 する方法を提案する。これをピクトグラムの 2 コマ表現と 以後表記する。

\section{2 ピクトグラムの 2 コマ表現の例}

公共交通機関や他の公共機関で実際に用いられているピク トグラムを題材に 2 コマ表現の作成を試みた.

表 1 に 2 コマ表現の例を 12 テーマ示す．表 1 において, カラム“1コマ表現”とはいわゆる静止画のピクトグラムを いう，本論文では以後 2 コマ表現との対比から，あえて 1 コ マ表現と表記する。 また表 1 でカラム“状況”とはピクトグラ ムが用いられている場所, カラム“説明文”とは, 公共の場で 実際にピクトグラムに付記されている説明文である.

次に各テーマの作成意図について説明する.

1）かばんのテーマでは, 1 コマ表現の場合, かばんの色 が赤であることから，それを意識させたいことは認識 できるが, 具体的な動作を想起することは困難であ る. 推奨動作を認識するためには, 説明文を読む必要 がある、そこで, 2コマ表現では“かばんを持ち替える” という動作を表現するため, “かばんを背負っている 場面”から“かばんを前に持っている場面”というかば んの位置の変化を差異情報として提示した.

2）ドアのテーマでは, 矢印を使って人と屝との距離に注 目させたいことが伺える.2コマ表現ではさらに，ド アに近づきすぎている状態と禁止マークを重ねたピク トグラムを追加した。 ここでの差異情報とは, 人間の 位置のことである

3）エスカレータ (親子) のテーマでは, ピクトグラムに3 つの意味 (センテンス) が含まれているため, 非常にわ かりにくくなっている. 特に1コマ表現の場合, ピク
表 1 ピクトグラムの 1 コマ表現, 2 コマ表現例

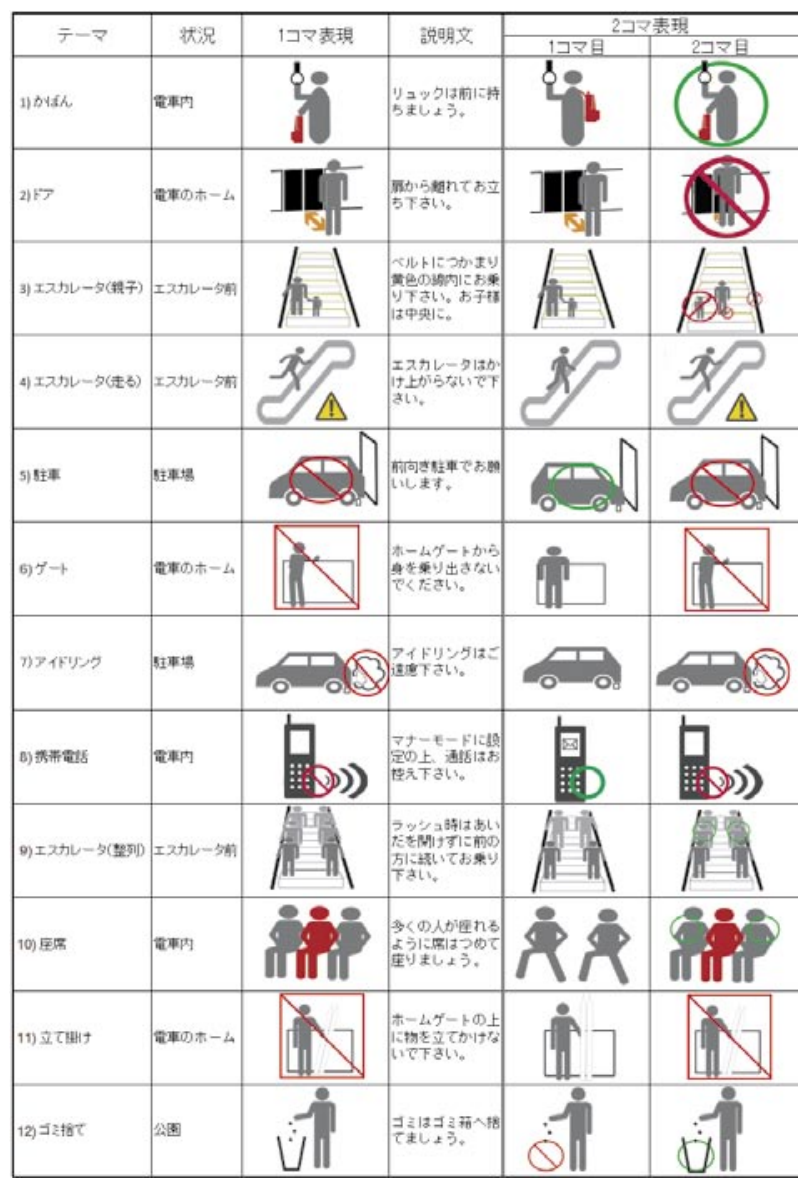

トグラムのどこに注意を払えばよいのかが分からない ため, 伝達内容の理解が困難である。そこで, 2 コマ 表現では, 禁止状態を表現したピクトグラムを2コマ 目に用意し，さらにその対応する箇所に禁止マークを 付けることで注目位置をより限定するようにした。

4）エスカレータ(走る)のテーマでは, 2 コマ表現の2コ マ目と1コマ表現とで同じピクトグラムを利用した。 $1 コ マ$ 目は, “走る”の対比である“歩く”を用いること で1コマ表現との差別化を図った。

5）駐車のテーマでは, 禁止マークの存在から, 車に関連 する禁止事項であることは推測できるが, この例も何 が具体的に禁止されているかがわかりにくい例であ る。例えば, 後ろ向き駐車が禁止であるという意味以 外にも, ここには駐車してはいけないという意味にも 解釈可能である。 そこで, 2 コマ表現では $1 コ マ$ 目に, 前向き駐車のピクトグラムを提示する. 車の向きとい う差分情報から駐車方向に関する警告を示すピクトグ ラムであることを推測させる.

6）ゲートのテーマでは，身を乗り出しているピクトグラ ムを1コマ表現と2コマ表現の2コマ目に利用した。 1 コマ目に, 通常の起立状態の人間を 1 コマ目に表現す ることで, 身を乗り出すという動作を差異情報と認識 し，かつそれが主題であることを認識させる.

7）アイドリングのテーマでは, アイドリングを複数の煙 
で表現している.アイドリングの様な表現しにくい概 念をいかに直感的に, 説明文無しに伝えるかはピクト グラムの研究で非常に重要である.

8）携帯電話のテーマでは, マナーモードを表現しょうと している. マナーモードは主に, 着信時に音を鳴らさ ずにバイブレータで振動を発するように動作するモー ドという意味で利用されるが, ピクトグラムによる表 現は容易ではない. 1コマ表現は通話を禁止すること を表現したピクトグラムとしては, 比較的理解が容易 であると言える。しかし, その禁止行為の対象を特定 しきれず, 本来なら許可されるべきマナーモードも禁 止されているという誤解を招く拉それがある。 そこで 2コマ表現では, 禁止行為の対象を限定化する．1コ マ目にマナーモードによる利用は禁止では無いことを “メール”をディスプレイ内部に表示することで印象づ ける.

9）エスカレータ(整列)のテーマは, 1) かばんのテーマと 同様, 指示動作の想起が非常に困難である. そこで, 2コマ表現では, “間を開けずに並ぶ”という指示動作 を，1コマ目に間を開けたピクトグラム，2コマ目に間 を詰めるという実際にユーザにしてもらいたい動作を 差分として提示する. さらに緑のマルという差分によ り推奨の意味を付加した。

10）座席のテーマも1）かばんのテーマと同じく, 一部が赤 い色で表現されているが, この色の変化で伝えたい内 容が不明である。そこで, 2コマ表現では，1コマ目に 必要以上の場所を使っている人を提示し, 2 コマ目に 1コマ目の人の姿勢を正したピクトグラムを示した。 詰めて座ることにより，もう一人座ることができるこ とを色の変化で示し, 正しく座ることを推奨の緑のマ ルを用いて表現した。

11）立て掛けのテーマは, 他の例と比べ理解しやすい内容 といえる.しかし，1コマ表現では, スキーボードの 所持自体が禁止なのか, 立て掛ける行為が禁止なのか わからない. そこで, 2コマ表現では, 1コマ目にスキー ボードを持っているピクトグラムを提示することで, 禁止が所持では無く, 行為であることを示している.

12）ゴミ捨てのテーマは, 禁止と推奨を同時に利用してい る.1コマ表現では, 表現内容が何を伝えたいのかが わかりにくい. そこで2コマ表現では，1コマ目にゴ ミのすぐ下に禁止マークを付与し，2コマ目にその位 置にゴミ箱を配置した。 これからゴミを捨てる対象と してのゴミ箱に主題があることを提示する.

以下表 1 で示した 12 テーマをもとに，ピクトグラムの 2 コマ表現について総合的に考察する.

禁止, 推奨, 限定などが JIS の標準案内図記号の利用意図 に示されているが, それらについては問題なく表現可能であ る. 禁止は“〜しないで下さい”という内容を表す. 表 1 に 示したテーマの内では2）ドア，3）エスカレータ（親子）, 5）駐車，6）ゲート，7）アイドリング，11）立て掛けが当
てはまる。これらのピクトグラムに共通する点は, 禁止マー クが用いられていることである。このマークも JIS 規格とし て定められているため，標識などで目にする機会が多い。ま た，禁止を示す赤を用いており，直感的にも理解しやすいと

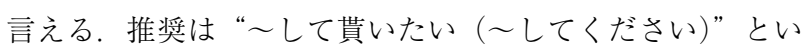
う要求を表現する。例の中では，1）かばん，9）エスカレー 夕 (整列)，10）座席，12）ゴミ捨てが相当する．推奨を表 す場合, 推奨前の行為は禁止事項で無いことが大半である. 例えば，1）かばんのテーマでは，“かばんは背負うのでは なく，前に持ちましょう”と要求している，かばんを背負う という行為(推奨前の行為) は禁止されてはいない. しかし, かばんを前に持つことで, より多くの乗客を乗せることがで きるため, 推奨行為を行ってもらえるように促している. 1 コマ表現の場合，かばんを前に持っているという状態は認識 が容易だが, 後ろから前に持ち替えるという行動要求の認識 は困難である。限定は，“〜はしてはいけません，しかし… はしてもかまわない”という内容を表現する。表 1 のテー マでは 8）携帯電話がそれに相当する，1コマ表現では，通 話と音だしが禁止であることは理解できるが，それ以外の行 為を行っても良いのか定かではない，そこで，2コマ表現で は, メールを行うことは許可し，通話や音を出すことは禁止 した。これにより，観察者に携帯電話の限定的な利用法を伝 えている.

また，注視すべき領域が認識しやすいという点もある．1 コマ表現では，注視すべき領域を明示する場合，色やサイズ を変化させることで対応していた。しかし，色やサイズを変 化させるだけでは，その変化が何を捉えているのかが特定し にくい場合が多い，そこで 2 コマ表現では，それらの変化 や差異情報を利用することで伝達内容の具体化を図ることが できる.

2 コマ表現について熟慮すべき点も存在する．2コマを時 間軸に沿って同一領域に続けて表示させる場合には，2 コマ 表現あることを明示しなければ, 変化が現れるか無変化であ ると分かるまで注視し続けなければならない.

一方, 表 1 の様 2 コマの画像を横並びに並列配置する表 示では, 2 コマの差異表現が直感的に分かりにくい.

2 コマ表現の内容を理解する上で，その提示順序は非常に 重要な要因である。例えば文章で考えると，「あの人はおっ ちょこちょいだけど, 頭は切れる.」は肯定的記述であり,「あ の人は頭は切れるけど, おっちょこちょいである」は否定的 否定的記述である。これは，人は後方刺激を重要と捉える 傾向にあるという言語学的知見の利用に由来する.よって表 1 に示す 2 コマ表現を作成するにあたり，伝えたい内容を表 現したピクトグラムを2コマ目に配置した。

\section{3. 実 験}

今回行った実験の趣旨と詳細, 被験者に関する情報, 実験 手順について述べる.

実験では，2 コマ表示から得られる差分情報がピクトグラ 

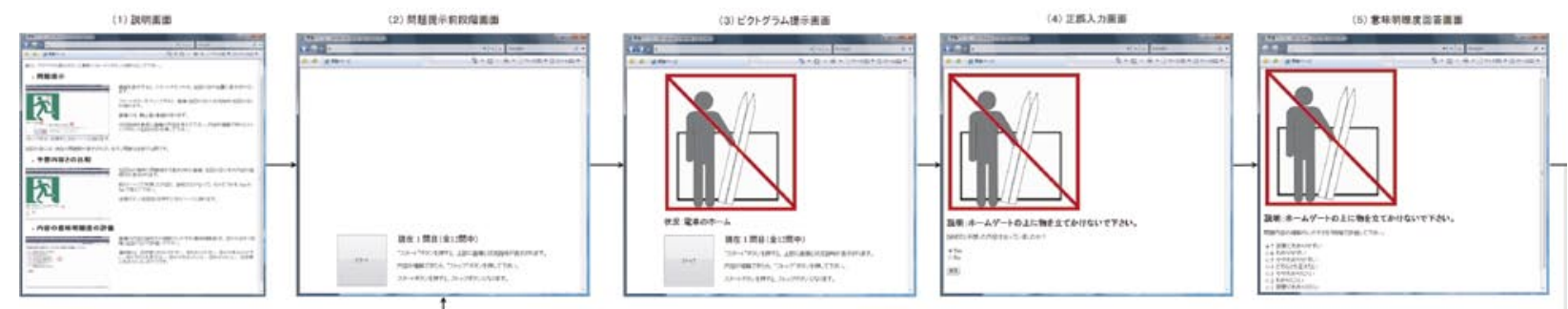

図 1 実験画面遷移図

ムの認識にどのように影響を与えるかを調査する。 あるセン テンスを表現した 2 コマ表現のピクトグラムあるいは $1 コ$ マ表現のピクトグラムをその利用状況と合わせて提示し, 反 応時間，一致率，意味明瞭度を測定した。 反応時間は，2 コ マ表現あるいは 1 コマ表現が提示されてから, 内容を理解 したと被験者が判断するまでの時間を計測したものであ る。一致率は, 公共の場で実際にピクトグラムに付記され ている説明文の内容と被験者が予想した内容とが一致して いたかをYes, Noで回答させた結果の比率である。意味 明瞭度は, 説明文の内容と提示されたピクトグラムがわか りやすかったかどうかを被験者に 7 段階で評価させた值で ある．７段階の評価は，7. 非常にわかりやすい，6.わかり やすい, 5. ややわかりやすい, 4. どちらとも言えない, 3. や やわかりにくい，2.わかりにくい，1. 非常にわかりにくい の中から選択させた。

2 章で概説した表 1 の 12 テーマを用意した. 1 つのテーマ につき, それぞれ 2 コマ表現と 1 コマ表現の 2 種類を用意し た. 各被験者には, 計 12 テーマそれぞれに対して, 2 コマ表 現もしくは 1 コマ表現を提示し回答させた. 1 コマ表現と 2 コマ表現でのテーマの重複が無いよう配慮した. 提示する際, テーマの提示順, 2 コマ表現が提示されるか 1 コマ表現が提 示されるかは乱数を用い, ランダムにした。 しかし，1コマ 表現と 2 コマ表現が 6 テーマずつにするようにした.

本実験の被験者は, 青山学院大学の学生 165 名である ${ }^{2}$. ピクトグラムについての予備知識が無い被験者を選び, 実験 を行うに当たっても, 特別な事前学習は行なっていない. 実 験には, パソコンを用い, 全てのテーマをブラウザ上で回答 させた，実験中，実施者は被験者に特別な指示は与えず，実 験の説明もブラウザ上で行った。それぞれのテーマについ て, 以下の手順で回答させた。図 1 に手順に沿った実験画 面遷移図を示す.

Step 1. 被験者は, 指定されたWebページにアクセスし, フォームに学生番号を入力後, “送信ボタン”をクリックする.

Step 2. 被験者は、実験の説明文を読み, その後“次へ”ボ夕 ンをクリックする(図1の画面(1)参照).

Step 3. 画面に, スタートボタン, 現在の回答テーマ数, 実 験の説明文が表示される(図1の画面 (2)参照)。被験者が“ス タートボタン”を押すと、ピクトグラム（1コマ表現あるいは 2コマ表現) と状況説明が現れる。スタートボタンは“ストッ

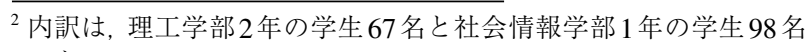
である
プボタン”に変わる。また、時間の計測が開始される（図1の 画面 (3)参照)。2コマ表現の場合は，1コマ目がスタートボ タン押下後 0 秒から 2 秒まで 1 コマ目を表示し, 2 秒以降は同 じ場所に2コマ目を表示し続ける。

Step 4. 被験者は, 提示されたテーマの内容を理解後, “久 トップボタン”を押す. ボタンを押すと、時間の計測を終える.

Step 5. テーマと内容説明文が表示され, 被験者は説明文と step 4 で予想した内容との正誤をYes (正), No (誤)の選択肢 から選び“送信ボタン”を押す(図1の画面(4)参照).

Step 6. 被験者は, テーマ内容のわかりやすさ (明瞭度)を7 段階で評価し, “送信ボタン”を押す。

Step 3 から Step 6 をすべてのテーマについて繰り返す. 全 テーマを回答した後，実験終了の旨を画面に表示する.

反応時間, 一致率, 意味明瞭度の観点から結果を集計した. その結果, 意味明瞭度に関して検定が必要と考えた。意味明 瞭度は正規性が検出されなかったため, マン・ホイットニー の $\mathrm{U}$ 検定を用い, 1 コマ表現と 2 コマ表現の間で意味明瞭 度に有意差が認められるかを検証した。

\section{4. 実験の結果と考察}

本章では, 主にテーマ別の結果と個人別の結果の観点から 結果の提示と考察を行う.

表 2 に実験結果を示す. 表 3 に 2 コマ表現と 1 コマ表現 の意味明瞭度に対してU 検定を行った結果を示す。表 3 に おいて, E (U) は統計量 U の期待值, V (U) は分散, Z は正規得点を表す.

1 コマ表現よりも2 コマ表現の意味明瞭度の方が高いとい う有意な差を，1）かばん（p<0.01），5）駐車（p<0.01）, 9）エスカレータ（整列）（p<0.01），10）座席（p<0.01） の 4 テーマに抏て見いだすことができた。 これら 4 テー マの共通点として, 推奨を表す緑のマルの利用, 1 コマ表現 の意味の不明瞭さが挙げられる．5）駐車を除く 3 テーマで は 1 コマ表現には推奨や禁止など, ピクトグラムから成す ベき行為を想起しにくい点が強く影響していると考えられ る. そのため, 2 コマ表現で推奨行為の差分情報から行為を 特定でき，一致率，意味明瞭度が上昇したと考えられる。

一方，5）駐車のテーマでは，1コマ表現に禁止マークが あるにもかかわらず，明瞭度に有意差が見いだされた。 その 原因として内容の不明瞭さが関係していると考えられる. 詳 
表 2 実験結果

\begin{tabular}{|c|c|c|c|c|c|c|c|c|c|c|c|c|c|}
\hline \multirow{2}{*}{ テーマ } & \multirow{2}{*}{$\begin{array}{l}\text { 表現 } \\
\text { 方式 }\end{array}$} & \multicolumn{5}{|c|}{ 明瞭度回答数 } & & & \multirow{2}{*}{$\begin{array}{c}\text { 明瞭度 } \\
\text { 正均 }\end{array}$} & \multirow{2}{*}{$\begin{array}{l}\text { 明瞭度 } \\
\text { 分散 }\end{array}$} & \multirow{2}{*}{ 一致率 } & \multirow{2}{*}{$\begin{array}{c}\text { 平均 } \\
\text { 反応時間 }\end{array}$} & \multirow{2}{*}{$\begin{array}{l}\text { 反応時間 } \\
\text { 分散 }\end{array}$} \\
\hline & & 1 & 2 & 3 & 4 & 5 & 6 & 7 & & & & & \\
\hline \multirow{2}{*}{ 1) かばん } & 1 コマ & 4 & 14 & 12 & 5 & 15 & 9 & 24 & 4.639 & 4.112 & 0.639 & 5.603 & 10.476 \\
\hline & 2_コマ & 1. & -3 & 2 & 2 & 16 & 19 & 39 & 5.951 & 1.899 & 0.939 & 4.879 & 8.290 \\
\hline \multirow{2}{*}{ 2) ド ア } & 1コマ & $\overline{4}$ & $\overline{4}$ & $\overline{7}$ & $\overline{7}$ & $1 \overline{5}$ & $\overline{15}$ & $2 \overline{7}$ & 5.253 & 3.243 & 0.810 & 5.095 & 12.490 \\
\hline & 2コマ & 2 & 10 & 10 & 4 & 17 & 15 & 28 & 5.105 & 3.436 & 0.791 & 5.298 & 12.329 \\
\hline \multirow{2}{*}{ 3）エスカレータ(親子) } & $1 \sqsupset \bar{~}$ & $\overline{7}$ & $\overline{15}$ & $\overline{1} \overline{7}$ & 13 & $1 \overline{1}$ & $\overline{15}$ & 13 & 4.132 & 3.627 & 0.560 & 4.715 & 9.768 \\
\hline & 2 コマ & 2 & 12 & 13 & 12 & 14 & 9 & 12 & 4.338 & 3.131 & 0.649 & 6.964 & 50.945 \\
\hline \multirow{2}{*}{ 4) エスカレータ(走る) } & 1 コマ & 1 & 4 & 2 & 4 & 12 & $2 \overline{1}$ & 48 & 6.011 & 2.011 & 0.935 & 3.972 & 8.220 \\
\hline & 2_コマ & 2 & 2 & $\underline{5}$ & 3 & 15 & 12 & 34 & 5.726 & 2.535 & 0.890 & 4.472 & 4.246 \\
\hline \multirow{2}{*}{ 5）駐車 } & 1コマ & $\overline{17}$ & $\overline{27}$ & $\overline{16}$ & $\overline{5}$ & $\overline{5}$ & $\overline{3}$ & $\overline{7}$ & 2.888 & 3.266 & 0.238 & 5.645 & 12.206 \\
\hline & 2_コマ & 1 & 1 & 3 & 2 & 9 & 26 & 43 & 6.141 & 1.504 & 0.941 & 5.052 & 6.076 \\
\hline \multirow{2}{*}{ 6) ゲート } & 1コマ & 3 & $\overline{7}$ & 9 & 4 & 12 & $\overline{16}$ & 30 & 5.259 & 3.519 & 0.778 & 4.444 & 6.985 \\
\hline & 2 コマ & 3 & 10 & 11 & 3 & 19 & 18 & 20 & 4.893 & 3.398 & 0.774 & 5.466 & 7.194 \\
\hline \multirow{2}{*}{ 7) アイドリング } & 1コマ & 6 & $1 \overline{5}$ & 8 & 10 & $\overline{17}$ & 14 & 19 & 4.517 & 3.889 & 0.618 & 4.128 & 11.393 \\
\hline & 2_コマ & 3 & -7 & 10 & 6 & 12 & 14 & 24 & 5.039 & 3.558 & 0.724 & 4.678 & 3.148 \\
\hline \multirow{2}{*}{ 8) 携帯電話 } & 1コマ & 1 & $\overline{9}$ & $\overline{11}$ & 7 & $\overline{15}$ & $\overline{11}$ & 25 & 5.013 & 3.320 & $0 . \overline{74} \overline{7}$ & $3.60 \overline{7}$ & 5.386 \\
\hline & 2_コマ & 2 & 12 & 16 & 4 & 13 & 11 & 28 & 4.849 & 3.871 & 0.744 & 4.597 & 11.897 \\
\hline \multirow{2}{*}{ 9) エスカレータ(整列) } & 1 コマ & 18 & $2 \overline{1}$ & $\overline{16}$ & 11 & 4 & $\overline{1}$ & 6 & 2.857 & 2.940 & 0.130 & 7.743 & 31.364 \\
\hline & 2_コマ & 11. & 17 & 18 & 10 & 13 & $\underline{6}$ & 13 & 3.761 & 3.839 & 0.511 & 6.573 & 17.442 \\
\hline \multirow{2}{*}{ 10）座席 } & $1 \sqsupset マ$ & 13 & 15 & 13 & 7 & 12 & 8 & 10 & 3.692 & 4.112 & 0.564 & 6.630 & 14.505 \\
\hline & 2 コマ & 2 & 3 & 8 & 11 & 14 & 18 & 31 & 5.414 & 2.664 & 0.874 & 7.881 & 169.639 \\
\hline \multirow{2}{*}{ 11）立て掛け } & 1コマ & 7 & 23 & $\overline{11}$ & $\overline{11}$ & 6 & $\overline{13}$ & 8 & 3.722 & 3.716 & 0.468 & 4.986 & 7.493 \\
\hline & 2_コマ & 15 & 16 & 17 & 10 & 11. & 5 & 12 & 3.570 & 3.989 & 0.477 & 6.289 & 16.993 \\
\hline \multirow{2}{*}{ 12) ゴミ捨て } & 1 コマ & 0 & 3 & 0 & 3 & 5 & 14 & 57 & 6.415 & 1.332 & $0.95 \overline{1}$ & 4.225 & 6.789 \\
\hline & 2 コマ & 0 & 1 & 3 & 3 & 10 & 12 & 54 & 6.301 & 1.359 & 0.976 & 4.012 & 6.808 \\
\hline
\end{tabular}

表 3 意味明瞭度に関する U 検定結果

\begin{tabular}{l|rcccl}
\hline \multicolumn{1}{c|}{ テーマ } & \multicolumn{1}{c}{$\mathrm{U}$} & $\mathrm{E}(\mathrm{U})$ & $\mathrm{V}(\mathrm{U})$ & $\mathrm{Z}$ & $\mathrm{P}$ 值 \\
\hline 1) かばん & 2174 & 3403 & 87657.43 & 4.152 & 0.000032852 \\
2) ドア & 3256 & 3397 & 89063.04 & 0.472 & 0.6365944 \\
3) エスカレータ(親子) & 3157 & 3367 & 90915.10 & 0.696 & 0.4861357 \\
4) エスカレータ(走る) & 3033 & 3358 & 80334.88 & 1.147 & 0.2515258 \\
5) 駐車 & 724 & 3400 & 90151.64 & 8.912 & $4.99 \mathrm{E}-19$ \\
6) ゲート & 2937 & 3402 & 89776.22 & 1.552 & 0.1206788 \\
7) アイドリング & 2847 & 3382 & 90506.87 & 1.779 & 0.07507683 \\
8) 携帯電話 & 3270 & 3397 & 89556.14 & 0.424 & 0.6712879 \\
9) エスカレータ(整列) & 2473 & 3388 & 90817.93 & 3.038 & 0.002382381 \\
10) 座席 & 1775 & 3393 & 91193.71 & 5.358 & $8.42 \mathrm{E}-08$ \\
11）立て掛け & 3245 & 3397 & 91477.97 & 0.504 & 0.6141137 \\
12）ゴミ捨て & 3214 & 3403 & 65042.57 & 0.741 & 0.4586472 \\
\hline
\end{tabular}

しくは 2 章で述べたが, このピクトグラムでは, 禁止マー クが何を禁止しているのか特定が難しい，そのため，推奨と 禁止を対比できた 2 コマ表現との間に有意差が見いだされ たと考えられる。1コマ表現の改善案として, 奥あるいは手 前に前向き駐車の車を並べることが考えられる. 他の車が前 向きであることが明示されていれば, 禁止対象の特定が容易 になる。

しかし，上記の 4 テーマ以外に，12）ゴミ捨て，8）携帯 電話のテーマにおいて推奨の緑のマルを利用したが, 有意差 は見いだされなかった，その理由はいくつか考えられるが, 1 コマ表現, 2 コマ表現共に高い一致率, 意味明瞭度が得ら れていることから，このテーマが広く浸透したピクトグラム であることが影響したと考えている．各公共交通機関では， 利用者のマナー向上を目指し，マナーモードの徹底を促して
いる。そのため, 実験者は被験者に対して, 実験前にピクト グラムについての学習や説明は行っていないが, 公共交通機 関の利用時にテーマ8の内容を事前に学習している可能性 が高い. また，同様に公園にはゴミ捨てマナー向上のための ピクトグラムや, 説明が多数存在するため, 両者のテーマは 推奨を利用せずとも十分に内容を推測できたと考えられる.

表 4 に個人別の正誤に基づいた実験結果を示す. 個人別 に集計を行ったところ，正答の場合，意味明瞭度と反応時間 に弱い負の相関があることが明らかになった（r<-0.39）. また, 正答の場合に意味明瞭度は高い值を示し (平均 5.69), 誤答の場合には低い值を示している（平均 2.58）ことから 回答の正誤と意味明瞭度には相関があることが予想される. 実験では, 被験者に2 コマ表現が切り替わるタイミング（2 秒）を知らせずに実験を行った。 そのため，表示されている テーマが 1 コマ表現か 2 コマ表現か確認するために最低 2 秒の時間が必要となる。つまり，2 コマ表現の 2 コマ目を見 ることなく回答した被験者がいるということである。そこ で，2秒未満の回答者数に関する結果を表 5 に示す.

4）エスカレータ（走る）のテーマでは，1コマ表現での 正答者数の割合が大きい。これは，1コマ表現が2 コマ表現 の 2 コマ目と同じであることと関係していると考えられる. 2 コマ表現では，伝えたい内容を表現したピクトグラムを 2 コマ目に配置したため, それを見ていない回答者よりも良い 結果が得られたと推測できる.

さらに, 1 コマ表現における概要把握の容易さも影響して いると考えられる．表2における4）エスカレータ（走る） の正答率は 1 コマ表現，2 コマ表現共に非常に高い数值を示 
表 4 正答・誤答別の実験結果

\begin{tabular}{|c|c|c|c|c|c|c|c|c|c|c|c|}
\hline \multirow[b]{2}{*}{ テーマ } & \multirow[b]{2}{*}{ 表現方式 } & \multicolumn{5}{|c|}{ 正答 } & \multicolumn{5}{|c|}{ 誤答 } \\
\hline & & $\begin{array}{l}\text { 回 } \\
\text { 答 } \\
\text { 数 }\end{array}$ & $\begin{array}{l}\text { 平均 } \\
\text { 反応 } \\
\text { 時間 }\end{array}$ & $\begin{array}{l}\text { 反応 } \\
\text { 時間 } \\
\text { 分散 }\end{array}$ & $\begin{array}{c}\text { 意味 } \\
\text { 明瞭度 } \\
\text { 平均 }\end{array}$ & $\begin{array}{c}\text { 意味 } \\
\text { 明瞭度 } \\
\text { 分散 }\end{array}$ & $\begin{array}{l}\text { 回 } \\
\text { 答 } \\
\text { 数 }\end{array}$ & $\begin{array}{l}\text { 平均 } \\
\text { 反応 } \\
\text { 時間 }\end{array}$ & $\begin{array}{l}\text { 反応 } \\
\text { 時間 } \\
\text { 分散 }\end{array}$ & $\begin{array}{c}\text { 意味 } \\
\text { 明瞭度 } \\
\text { 平均 }\end{array}$ & $\begin{array}{c}\text { 意味 } \\
\text { 明瞭度 } \\
\text { 分散 }\end{array}$ \\
\hline 1) & 1 コマ & 53 & 5.05 & 11.56 & 5.85 & 1.78 & 30 & 6.58 & 7.34 & 2.50 & 1.02 \\
\hline & 2 2コマ & 77 & 4.65 & 6.90 & 6.16 & 1.13 & 5 & 7.65 & 26.17 & 2.80 & 3.70 \\
\hline & 1コマ & $\overline{6}$ & 4.44 & 9.26 & 5.89 & 1.53 & $\overline{1} \overline{5}$ & 7.82 & 17.99 & $2.53^{-}$ & 1.41 \\
\hline & 2 コマ & 68 & 4.88 & 9.59 & 5.72 & 1.94 & 18 & 6.89 & 20.44 & 2.78 & 2.30 \\
\hline & 1ココマ & 51 & 4.37 & 6.35 & 5.27 & 2.44 & $\overline{4}^{-}$ & 5.15 & 14.05 & 2.68 & 1.35 \\
\hline - & 2_コマ & 48 & 5.74 & 18.76 & 5.13 & 2.37 & 26 & 9.22 & 105.34 & 2.88 & 1.31 \\
\hline 4) 7 & 1コマ & 86 & 3.79 & 7.04 & 6.27 & 1.07 & 6 & 6.55 & 21.31 & 2.33 & 1.07 \\
\hline 4) & 2_コマ & 65 & 4.46 & 4.56 & 6.11 & 1.35 & 8 & 4.54 & 2.00 & 2.63 & 1.41 \\
\hline 5) 駐東 & 1コ元 & 19 & 5.16 & 29.03 & 5.16 & 3.14 & $\overline{6} 1$ & 5.80 & 7.26 & 2.18 & 1.22 \\
\hline 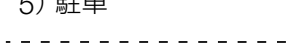 & _2コマ & 80 & 5.05 & 6.34 & 6.33 & 0.98 & 5 & 5.05 & 2.36 & 3.20 & 0.70 \\
\hline & 1コ元 & 63 & 3.94 & 4.64 & 5.97 & 1.64 & $\overline{18}$ & 6.20 & 11.73 & 2.78 & 2.18 \\
\hline & 2 コマ & 65 & 5.25 & 5.17 & 5.54 & 2.16 & 19 & 6.21 & 14.03 & 2.68 & 1.34 \\
\hline & 1コマ & 55 & 3.51 & 3.54 & 5.75 & 1.60 & 34 & 5.12 & 22.94 & 2.53 & 1.17 \\
\hline & 2 コマ & 55 & 4.56 & 2.75 & 5.91 & 1.68 & 21 & 4.99 & 4.25 & 2.76 & 1.29 \\
\hline 8）㨦帯雷話 & 1コ元 & 59 & 3.73 & 6.25 & 5.76 & 1.91 & $20^{-}$ & 3.24 & 2.85 & 2.80 & 0.91 \\
\hline O) & 2.コマ & 64 & 4.71 & 8.38 & 5.67 & 2.29 & 22 & 6.97 & 19.05 & 2.45 & 0.74 \\
\hline & 1コマ & 10 & $4.80^{-}$ & $8.80^{-}$ & $4.70^{-}$ & 3.79 & $\overline{6} \overline{7}$ & 8.18 & 33.41 & 2.58 & 2.28 \\
\hline 9) $\perp$ & 2 2コマ & 45 & 5.19 & 4.93 & 5.20 & 2.34 & 43 & 8.03 & 26.01 & 2.26 & 0.89 \\
\hline & 1コマ & 44 & 5.92 & 15.76 & 5.00 & 2.79 & $\overline{3} 4$ & 7.55 & 11.75 & 2.00 & 0.73 \\
\hline & 2 コマ & 76 & 7.56 & 188.20 & 5.74 & 2.04 & 11 & 10.10 & 36.87 & 3.18 & 1.11 \\
\hline 11）衣て掛け & 1コマ & 37 & 4.38 & 7.29 & 5.27 & 2.42 & $\overline{4} 2^{-}$ & 5.52 & 7.23 & 2.36 & 0.87 \\
\hline (1) 1 & _2_コマ & 41 & 5.49 & 22.85 & 5.22 & 2.18 & 45 & 7.02 & 10.92 & 2.07 & 0.88 \\
\hline & 1コマ & $\overline{7} 8$ & 4.17 & 6.79 & 6.62 & 0.53 & $-\overline{4}$ & 5.27 & 7.56 & 2.50 & 1.00 \\
\hline 12）」二搭 & 2 コマ & 81 & 4.07 & 6.84 & 6.40 & 1.02 & 2 & 1.84 & 1.76 & 2.50 & 0.50 \\
\hline
\end{tabular}

している，また，2秒以下での回答は 1 コマ表現の正答者の 3 割である。これらの結果から, 被験者によっては, 全体像 を把握しやすい 1 コマ表現の方が 2 コマ表現よりも適する 可能性が示唆される.7）アイドリングのテーマも同様であ る. 1 コマ表現の正答数が高く, 2 コマ表現は少ない. 理由 として, 前述の 1 コマ表現の全体像を把握しやすい点があ る。またそれだけでなく，2コマ表現で回答者が少なかった 理由に，1コマ目の役割が影響していると考えられる．2 コ マ表現は 1 コマ目あるいは2 コマ目だけの提示では, 全体 の表現内容が完結しない場合がある。1コマ目のピクトグラ ムは車が止まっているだけであり，2コマ目を提示されない ことには, 内容を推測できない. そのため, 多数の被験者は 2 コマ目の提示を待つために 2 秒以上の時間を要したと考え られる。

表 5 の結果において, 回答時間が 2 秒以下にも関わらず, 高い正答率が得られているテーマがいくつか存在する。 その 要因は 1 コマ表現, 2 コマ表現の表現内容に強く影響し，1 コマ表現の内容がわかりやすい，あるいは広く認知されてい る場合には，1コマ表現は瞬時に認識が可能であることが示 唆された。しかし, 今回は集団の母数が少ないため, より詳 細な設定の元での実験が必要になるであろう.

ここからは, 今回提案したピクトグラムの 2 コマ表現を 実際に利用する状況を想定した場合に考えられる考慮点につ いて述べる。

2 コマ表現の実利用時の考慮点として, 他の年齢での被験
表 52 秒未満の回答者数及びその割合

\begin{tabular}{|c|c|c|c|c|}
\hline \multirow{2}{*}{ テーマ } & \multicolumn{2}{|c|}{ 1コマ表現 } & \multicolumn{2}{|c|}{2 コマ表現 } \\
\hline & 正答 & 誤答 & 正答 & 誤答 \\
\hline 1) かばん & $\begin{array}{r}7 \\
(13.2 \%)\end{array}$ & $\begin{array}{r}0 \\
(0.0 \%)\end{array}$ & $\begin{array}{r}10 \\
(13.0 \%)\end{array}$ & $\begin{array}{r}1 \\
(20.0 \%)\end{array}$ \\
\hline 2) ドア & $\begin{array}{r}10 \\
(15.6 \%)\end{array}$ & $\begin{array}{r}0 \\
(0.0 \%)\end{array}$ & $\begin{array}{r}11 \\
(16.2 \%)\end{array}$ & $\begin{array}{r}0 \\
(0.0 \%)\end{array}$ \\
\hline $\begin{array}{l}\text { 3) エスカレータ } \\
\text { (親子) }\end{array}$ & $\begin{array}{r}10 \\
(19.6 \%)\end{array}$ & $\begin{array}{r}6 \\
(15.0 \%)\end{array}$ & $\begin{array}{r}8 \\
(16.7 \%)\end{array}$ & $\begin{array}{r}2 \\
(7.7 \%)\end{array}$ \\
\hline $\begin{array}{l}\text { 4) エスカレータ } \\
\text { (走る) }\end{array}$ & $\begin{array}{r}28 \\
(32.6 \%)\end{array}$ & $\begin{array}{r}1 \\
(16.7 \%)\end{array}$ & $\begin{array}{r}8 \\
(12.3 \%)\end{array}$ & $\begin{array}{r}1 \\
(12.5 \%)\end{array}$ \\
\hline 5) 駐車 & $\begin{array}{r}4 \\
(21.1 \%)\end{array}$ & $\begin{array}{r}0 \\
(0.0 \%)\end{array}$ & $\begin{array}{r}6 \\
(7.5 \%)\end{array}$ & $\begin{array}{r}0 \\
(0.0 \%)\end{array}$ \\
\hline 6) ゲート & $\begin{array}{r}9 \\
(14.3 \%)\end{array}$ & $\begin{array}{r}1 \\
(5.6 \%)\end{array}$ & $\begin{array}{r}4 \\
(6.2 \%)\end{array}$ & $\begin{array}{r}3 \\
(15.8 \%)\end{array}$ \\
\hline 7) アイドリング & $\begin{array}{r}13 \\
(23.6 \%)\end{array}$ & $\begin{array}{r}5 \\
(14.7 \%)\end{array}$ & $\begin{array}{r}3 \\
(5.5 \%)\end{array}$ & $\begin{array}{r}1 \\
(4.8 \%)\end{array}$ \\
\hline 8）携帯電話 & $\begin{array}{r}12 \\
(20.3 \%)\end{array}$ & $\begin{array}{r}3 \\
(15.0 \%)\end{array}$ & $\begin{array}{r}9 \\
(14.1 \%)\end{array}$ & $\begin{array}{r}3 \\
(13.6 \%)\end{array}$ \\
\hline $\begin{array}{l}\text { 9) エスカレータ } \\
\text { (整列) }\end{array}$ & $\begin{array}{r}2 \\
(20.0 \%)\end{array}$ & $\begin{array}{r}3 \\
(4.5 \%)\end{array}$ & $\begin{array}{r}4 \\
(8.9 \%)\end{array}$ & $\begin{array}{r}6 \\
(14.0 \%)\end{array}$ \\
\hline 10）座席 & $\begin{array}{r}7 \\
(15.9 \%)\end{array}$ & $\begin{array}{r}0 \\
(0.0 \%)\end{array}$ & $\begin{array}{r}10 \\
(13.2 \%)\end{array}$ & $\begin{array}{r}1 \\
(9.1 \%)\end{array}$ \\
\hline 11）立て掛け & $\begin{array}{r}3 \\
(8.1 \%)\end{array}$ & $\begin{array}{r}5 \\
(11.9 \%)\end{array}$ & $\begin{array}{r}3 \\
(7.3 \%)\end{array}$ & $\begin{array}{r}0 \\
(0.0 \%)\end{array}$ \\
\hline 12) ゴミ捨て & $\begin{array}{r}11 \\
(14.1 \%) \\
\end{array}$ & $\begin{array}{r}0 \\
(0.0 \%) \\
\end{array}$ & $\begin{array}{r}19 \\
(23.5 \%)\end{array}$ & $\begin{array}{r}1 \\
(50.0 \%) \\
\end{array}$ \\
\hline
\end{tabular}

者でも同様の結果が得られるかが考えられるであろう。我々 はこれまでに, 静止画（1コマ表現）ピクトグラムの年代別 の理解度調査を紙ベースで行っている [11]. 実験では, 小 学校低学年から 70 代の被験者を対象としており, その結果 
50 代以降に認識率の低下が見られることがわかっている. また，ピクトグラムの内容が複雑になるにつれ回答を放棄す る傾向があることも見受けられた．この点に関しては，50 代以降認識率が低下すること, シンプルなピクトグラムは理 解度が高く, 複雑な内容ほど誤解されやすいことが, 三枝に よっても報告されている [12]，今回は PC 上で実験を行う こととしたため, PC 操作スキルに問題ない学生を実験対象 としたが, 本件においても, 同様の結果が得られると推察さ れる。

また，実環境ではある程度の距離から目視することにな る. そもそもピクトグラムには, 案内目的だけでなく, 避難 誘導や危険回避もその目的にあるため, 遠距離からもある程 度容易に視認できるよう考慮されている。しかしながら，ピ クトグラムの視認の容易さは, サイズ, 色, 形状などが複雑 に関係しているため, 実利用の際はピクトグラムの表示法に 若干の配慮が必要となるかもしれない.

さらに，すべての人が数秒かけて 2 コマ表現を見てくれ る訳ではないという点も考慮すべきであろう，今回の実験で 2 コマ表現は，1 コマ表現の内容補助を目的として利用され ることが多かった．実験で利用した 2 コマ表現は，2コマの うちのどちらかに 1 コマ表現とほぼ同じ, あるいは全く同 じピクトグラムが利用されている，さらに，実際に利用され ているテーマを基にピクトグラムを作成したため, 多少の事 前学習が行われていると考えられる。 それにより，1コマ目 だけでもその内容を理解できると考えられる. 図 2 に個人 別の平均反応時間の累積度数グラフを示す。横軸は時間 (秒), 縦軸は回答者の人数を表す。また, 図 3 から図 6 に, テーマ1）かばん, テーマ7）アイドリング, テーマ8）携 帯電話, テーマ9）エスカレータ（整列）に打り反応時間 の累積比率のグラフを示す。横軸は時間（秒）, 縦軸は回答 者の比率を表す，累積であるため，横軸の時間までに回答さ れた回答数の比率となることを注意されたい. 例えば図 3 に おいて, 横軸の 2.8 という数值では, 2.8 秒までに被験者の $20 \%$ が回答したことを表現している. グラフ内の赤い点線 は，2秒の時に 2 コマ表現の 2 コマ目を提示したことを表し

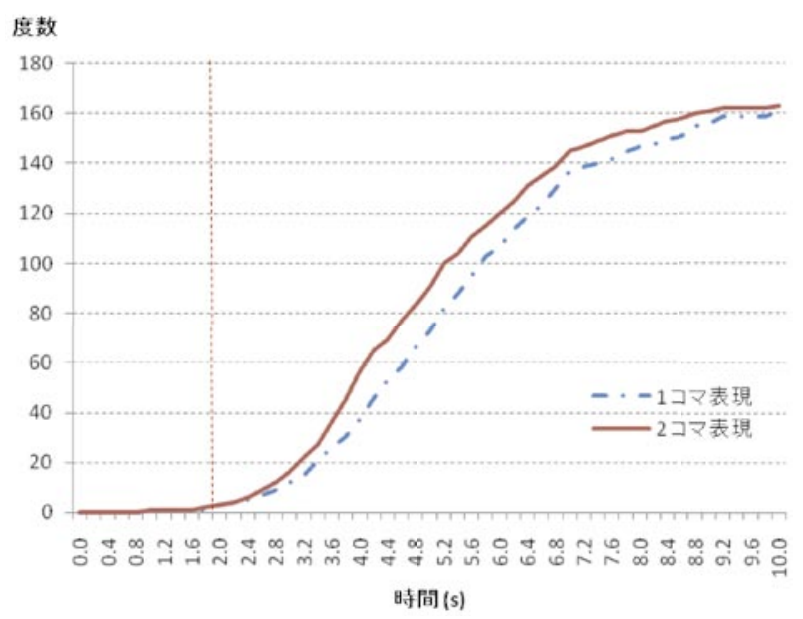

図 2 個人別平均反応時間の累積度数

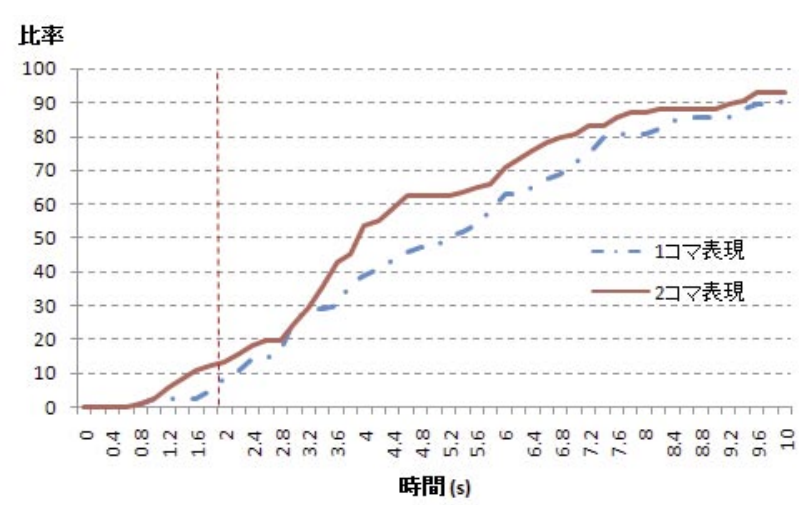

図 3 反応時間の累積比率（テーマ1かばん）

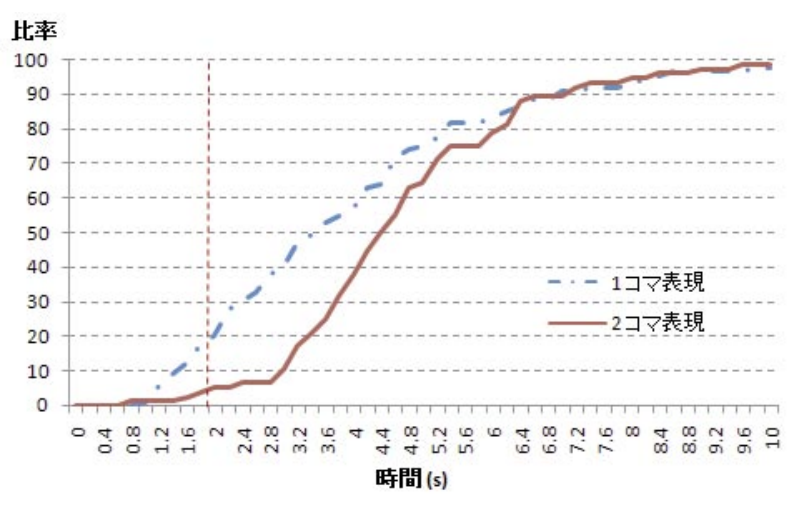

図 4 反応時間の累積比率（テーマ7アイドリング）

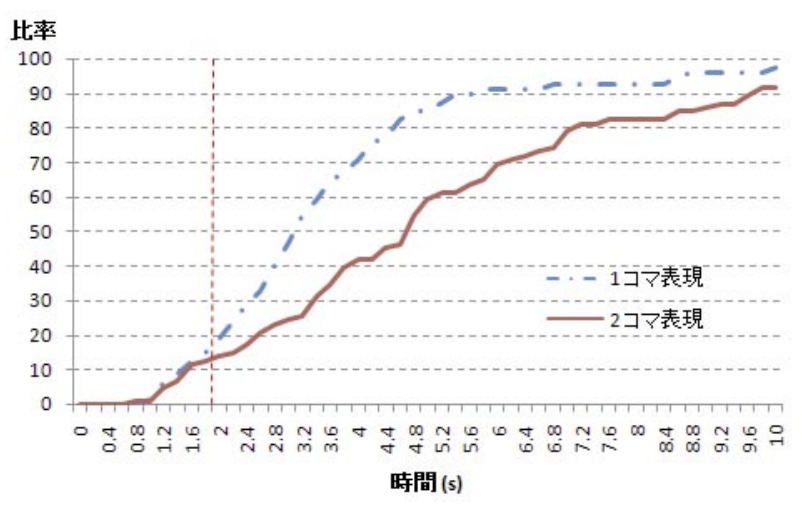

図 5 反応時間の累積比率（テーマ 8 携帯電話）

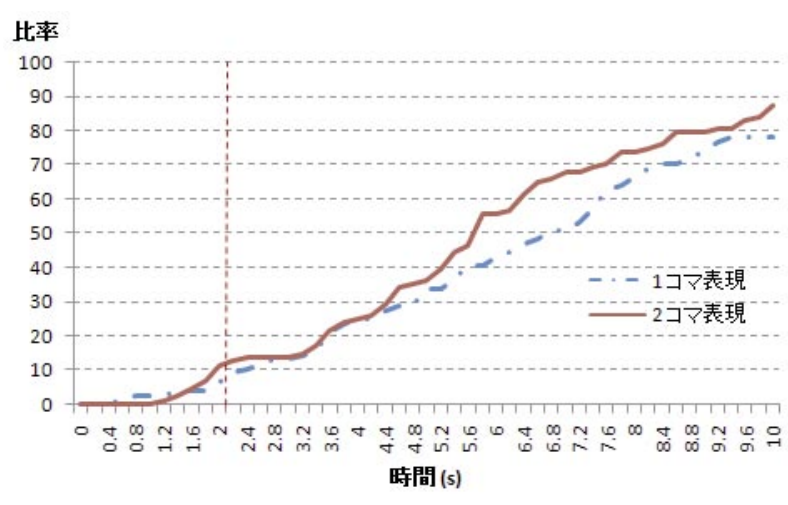

図 6 反応時間の累積比率（テーマ9 エスカレータ(整列)） 
ている. 比率が 100\%に達していないのは, 回答に 10.0 秒 以上要した被験者が存在するためである。ここではわかりや すさを考慮し 10.0 秒までの表示とした，また，傾きが急な ほど，その時間範囲（0.2 秒間）における回答数が多かった ことを表している.

テーマ8）携帯電話の結果を表した図 5 のグラフでは, 1 コマ表現の回答の収束時間が非常に早い.これは前述の通 り, 被験者の事前学習に強い影響を受けている。被験者は, 日頃の経験から, 電車内という状況と携帯電話のピクトグラ ムと禁止マークを見ることにより，マナーモードに設定する こと，通話は禁止であることを反射的に予測していると考え られる。一方, 2 コマ表現の場合, 1 コマ目の情報がその推 測を導き出すことを阻害してしまっていると考えられる。そ のため, このテーマでは, 1 コマ表現で非常に顕著な結果が 見られたと言える。この様に, 1 度学習が行われれば, 次回 以降 2 コマ目の提示は不要であり, 認識に必要な時間はご く短時間で済む.

事前学習が行われていない場合には，1コマ目と2コマ目 を別々に観察し，その後両者の差分から意味把握を行うとい う手法が考えられる. 例えば, ある地点に1コマ目を表示し, 少し離れた別の地点に 2 コマ目を表示する. 観察者はそこ を通過することで2コマを認識し, その差分から意味の把 握を行うことも考えられる. この手法では, 連続的な提示で ないことから, 即時の直感的理解は困難になると予想され る.しかし, 今回の 2 コマ表現では, 1 コマ表現と同じピク トグラムを利用してものもあるため, 片方だけの提示でも効 果があり, 十分な理解度が得られると考えられる. その他に も，見る角度を変えると別の画像が現れるといった特殊印刷 を利用した手法も考えられる。これには，画像の変化に時間 遷移を用いず，観察者の位置変化を用いることで，自分の夕 イミングで見ることができる。こちらは移動速度にも影響す るが，概ね連続提示の状況を作り出すことができるため，今 回の実験と同様の結果になると考えられる.

テーマ7)アイドリングの結果を表した図4のグラフでは, 2.8 秒から 5.2 秒の 2.4 秒間に比率が約 $70 \%$ 増加している. テーマ 1）かばんの結果を表した図 3 のグラフにも同様の傾 向が見られ，2.8 秒から 4.4 秒の 1.6 秒間に比率が, 約 $40 \%$ 増加している。 これは，2 コマ目を提示したことにより初め て意味が理解できた被験者が多くいることを示している。一 方，テーマ9）エスカレータ（整列）の結果を表した図 6 の グラフでは, 4 秒以降で 2 コマ表現の傾きが大きくなってい る.これは, 本テーマのピクトグラムに普段慣れ親しんでい ないことが影響していると考えられる，そのため，被験者は 2 コマ目を提示された後，2，3秒考えたのち内容がわかり， 4 秒以降の回答が増加したと考えられる. 3 つのテーマ全て において, 表 2, 表 4 の結果から意味明瞭度, 一致率につい て2コマ表現が非常によいことがわかる.

また，今回の実験では必ず表 1 に示した 1 コマ目，2コマ 目の順に提示した。しかし実利用時においては, タイミング によっては，2コマ目を先に見てしまう可能性も考えられ
る. 2 コマ目を先に見た場合, “人は後方刺激を重要と捉え る傾向がある”という言語学的知見の効果が薄れてしまう. しかし前述の通り，1 コマだけの単体提示でも十分な理解が 得られると考えられ，多少の精度の低下は見受けられるかも しれないが，概ね今回の実験と同程度の結果が得られるであ ろう.

\section{5. まとめと今後の課題}

本論文では，ピクトグラムの 2 コマ表示と 1 コマ表示の 認識特性を実験により調査し, 反応時間や一致率, 明瞭度の 結果に基づいてピクトグラム単体での認識向上について考察 した.いくつかのテーマに拈いて1コマ表現よりも2 コマ 表現の方が, 意味明瞭度や一致率の観点において優位性を見 いだすことができた．つまり類似ピクトグラムの連続提示か ら得られる様々な差異情報により，ピクトグラム単体での認 識向上が十分見込めると結論付けられる.

今回いくつかの点については, 既存の研究に基づいた推測 的考察にならざるを得なかった，実環境での実験を含めた， より詳細な検証が今後の課題である。ささらに，2コマ表示方 式や作成指針に関して研究を進め, その知見に基づいたピク トグラム表現やッールを幅広く流通させていきたいと考えて いる.

\section{謝 辞}

本研究の一部は科学研究費補助金（課題番号：20700097 研究代表者：伊藤一成）によるものです。ここに記して謝意 を表します。

\section{参 考文 献}

［1］太田幸夫：ピクトグラムのおはなし，日本規格協会，1995

[2] Krisela Rivera, Nancy J. Cooke and Jeff A. Bauhs: The effects of emotional icons on remote communication, Conference on Human Factors in Computing Systems, pp.99-100, 1996

[3] Maharaji, S.C.: Pictogram Ideogram Communication, The George Reed Foundation for the Handicapped, 1980

[4] Shi-Kuo Chang: Visual Languages: A Tutorial and Survey, Selected contributions on Visualization in programming, 5th Interdisciplinary Workshop in Informatics, pp.1-23, 1987

[5] Aaron Marcus: Icons, Symbols, and Signs: Visible Languages to Facilitate Communication, interactions, Issue 3 (may + june), pp.37-43, 2003

[6] ISO: ISO 7001 (Public Information Symbols), 1990

[7] IEC: IEC 60416 and 60417 (Graphical Symbols for Use on Equipment), 2005

[8］日本規格協会：JIS T0103(コミュニケーション支援用絵記 号デザイン原則)，2005

［9］日本規格協会：JIS Z 8210(標準案内図記号)，2002 
[10] 北神慎司：動画形式の視覚シンボルの視覚的典型性に関 する調査, 日本教育工学会論文誌, 30, pp.21-24, 2006

[11] 藤森誠, 伊藤一成, Martin J. Dürst, 橋田浩一：ピクトグ ラムの群配置における感性的認識に関する検証, 日本感性 工学会研究論文誌, 8, 2008

[12] 三枝 孝司：ピクトグラムの形態表現に関する研究：高齢 者対象や造形的要素をより考慮した標準案内用図記号案, 九州産業大学芸術学部研究報告, 38, pp.239-253, 2007

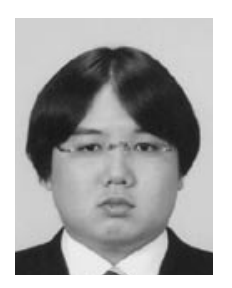

藤森 誠 (学生会員)

2007 年青山学院大学理工学部情報テクノロ ジー学科卒業. 現在, 同大学院理工学研究科 理工学専攻知能情報コース博士前期課程在学 中. 日本感性工学会, 日本認知科学会, 情報 処理学会, 各学生会員. ピクトグラムを用い たコミュニケーションに関する研究に従事.

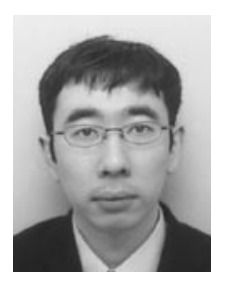

伊藤 一成 (非会員)

2005 年慶應義塾大学大学院理工学研究科後 期博士課程修了. 博士 (工学). 2005 年より 青山学院大学理工学部助手 (2007 年より助 教) 現在, 青山学院大学社会情報学部助教. セマンティックコンピューティング, 自然言 語処理及びマルチメディア情報処理に関する研究に従事. 情報 処理学会, 電子情報通信学会, 人工知能学会, 日本データベー 又学会, ACM 各会員.

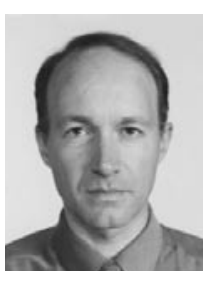

テュールストマーティンヤコブ (非会員) 1986 年チューリッヒ大学経済学部修士。 1990 年東京大学大学院理学研究科情報科学 専攻博士課程修了. 理学博士. チューリッヒ 大学情報科学科主任助手, 慶応義塾大学特別 研究助教授を経て, 現在, 青山学院大学理工 学部情報テクノロジー学科准教授. 専門はウェブやソフトウェ アの国際化. 情報処理学会, IEEE, ACM, Unicode 各会員.

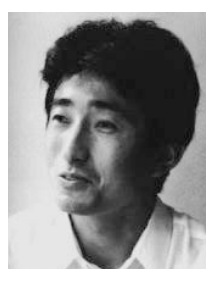

橋田 浩一 (非会員)

1986 年東京大学大学院博士課程修了. 理学 博士. 2001 年から産業技術総合研究所サイ バーアシスト研究センター副研究センター 長, 次いで研究センター長. 2004 年から同 情報技術研究部門副研究部門長，次いで部門 長. 現在はサービス工学研究センター次長. 最近の主な研究テー マは, 知的コンテンッ, セマンティックコンピューティング, 制約に基づくサービスのモデルなど. 日本認知科学会, 情報処 理学会, 言語処理学会, 社会言語科学会, 人工知能学会, 日本 ソフトウェア科学会各会員. 